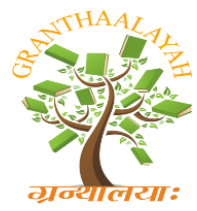

INTERNATIONAL JOURNAL OF RESEARCH GRANTHAALAYAH

A knowledge Repository

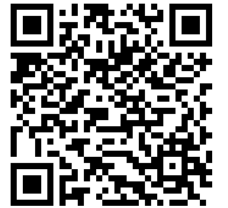

Science

\title{
DETERMINATION OF ANTIBACTERIAL ACTIVITY OF SOME IMPORTANT SPICES
}

\author{
Ranganathan Kapilan ${ }^{* 1}$ \\ ${ }^{* 1}$ Department of Botany, University of Jaffna, Jaffna, SRI LANKA
}

\begin{abstract}
Wide range of plant extracts are used for medicinal purposes as they are very cheap, efficient, harmless and do not cause any side effects. Spices are parts of different plants and they add special aroma and taste to the food preparations. The aim of the study was to determine the antimicrobial activity of some important naturally grown spices against gram positive and gram negative pathogenic bacteria. Antibacterial activity of the spices was tested against gram positive bacteria Bacillus pumilus, Bacillus cereus and Staphylococcus aureus and gram negative bacteria Escherichia coli, Salmonella typhi and Pseudomonas aeruginosa using aqueous, ethanolic, methanolic and liquid nutrient extracts. Among all the extracts tested alcoholic extracts of Cardamom (Elettaria cardamom), clove (Eugenia caryophyllus) and lemongrass (Cymbopogon citratus) showed maximum antimicrobial activity against gram negative bacteria while alcoholic extract of Cardamom (Elettaria cardamom) and lemongrass (Cymbopogon citratus) showed maximum activity against gram positive bacteria. All the spices tested in this study proved that they have antibacterial activity and the maximum activity index (1.39) was exhibited by the ethanol extract of cardamom against E.coli.
\end{abstract}

Keywords:

Antimicrobial activity; activity index; naturally grown spices; Bacillus; E.coli.

Cite This Article: Ranganathan Kapilan, "DETERMINATION OF ANTIBACTERIAL ACTIVITY OF SOME IMPORTANT SPICES" International Journal of Research Granthaalayah, Vol. 3, No. 10(2015): 57-64.

\section{INTRODUCTION}

Spices are widely used for flavoring foods since the ancient times, and as natural medicines against a variety of human diseases. Most of the Asian countries are rich heritage of traditional medical system and rich biodiversity of the diverse range of spices used for treatments (Pei, 2001). Spices could be a seed, fruit, root, bark, berry, bud or vegetable substance that is primarily used for flavoring, coloring or preserving food. Due to the presence of different chemicals and metabolites in different amount in the plant body, many spices exhibit antimicrobial properties. Spices are more commonly used in warmer climates, where infectious diseases is common. Usage of spices is prominent in meat, which is particularly susceptible to spoiling by microbes. Other 
than the medicinal usage, the spices are used for the production of cosmetics and perfume and sometimes they are directly consumed as fresh vegetables.

Medicinal plants constitute of primary and secondary metabolites which are of great therapeutic value (Evans et al, 2002). Medicinal plants play a major role in the traditional health care system of the rural population in developing Asian countries. People living in the remote areas of the developing countries in Asia and Africa depend on home care and traditional natural medicines for therapies. Most of these therapies are done using plant extracts. The plant extracts are used to treat wide range of diseases like asthma, urinary tract infection, intestinal disorder and recurrent fever. (Tenover et al, 2004, Chang, 1995). Further, the natural herbal treatments are famous and effective for their cost effective and ecofriendly aspects, in spite of the introduction of a number of different antibiotics by the pharmacological industries time to time (Arora and Kaur, 1999). Human body naturally develops resistance to some antibiotics in the long run, but the natural herbal or spices that are in practice have no such resistance. The development of resistance to conventional antimicrobials has been a serious issue in the invention of new medicines for both acute and chronic diseases. There has been more constant focus in the development of newer antimicrobial agents (Gold and Millering, 1995). Hence there is an increasing trend of using plants or plant products as therapeutic agents for the control of antibiotic resistant microbes (Mishra and Behal, 2010).

Although the primary purpose of spices is to improve the taste and aroma of the food preparations, they are important due to its medicinal, antimicrobial and antioxidant properties (Joe et al, 2009; Aneja et al, 2012). The spices have unique aroma and flavor due to the presence of different compounds known as phytochemicals or secondary metabolites (Avato et al, 2006, Panpatil et al, 2013). Numerous classes of phytochemicals including isoflavonoids, anthocyanins and flavonoids are found associated with the spices (Shan et al, 2007). There is a growing interest in using natural compounds in food protection instead of chemical preservatives (Abdel-Hammiad et al. 2009). Therefore, this study was planned to carry out a study on the antimicrobial effect of aqueous, methanolic, ethanolic and nutrient extract of common spices used in the general Asian dishes namely Cinnamon (Cinnamomum zeylanicum), cardamum (Elettaria cardamom), cumin seeds (Cuminum cyminum), Cloves (Eugenia caryophyllus), Lemongrass (Cymbopogon citratus) and Nutmeg (Myristica fragrans) against selected gram negative and gram positive bacteria.

The objective of this study was to test the plant extracts of some selected spices against a diverse range of organisms comprising Gram-positive and Gram-negative bacteria. The purpose of this was to create directly comparable, quantitative, plant antimicrobial data.

\section{MATERIALS AND METHODS}

\section{Spices used}

Spices used for the studies were Cinnamon (Cinnamomum zeylanicum), cardamum (Elettaria cardamom), cumin seeds (Cuminum cyminum), Cloves (Eugenia caryophyllus), Lemongrass (Cymbopogon citratus) and Nutmeg (Myristica fragrans). 


\section{Preparation of extract}

Air-dried and coarsely powdered material of the spices was extracted for 8 hours with distilled water in Soxhlet apparatus and then the extract was filtered and used for the study as aqueous extract. Similarly ethanol and methanol extracts and nutrient broth were prepared.

\section{Test organisms used}

Three gram positive and three gram negative organisms were used as test organisms in the study. Gram positive bacteria were Bacillus pumilus, Bacillus cereus and Staphylococcus aureus while gram negative bacteria were Escherichia coli, Salmonella typhi and Pseudomonas aeruginosa. All the cultures were maintained on nutrient agar slants.

\section{Determination of antimicrobial activity}

The antimicrobial activity of the extracts was carried out by well diffusion method (Parez et al, 1990) using $100 \mu \mathrm{L}$ of suspension containing $10^{8} \mathrm{CFU} / \mathrm{ml}$ of bacteria spread on nutrient agar (NA) medium. Sterile eight $\mathrm{mm}$ diameter cork borer was used to prepare well in the nutrient agar. Each well was filled with $0.1 \mathrm{ml}$ of extract of plant material. Negative control was prepared using the same solvents employed to prepare the plant extracts. Penicillin G (10U/disc), was used as a positive reference to determine the sensitivity of bacterial species tested. The inoculated plates were incubated at $37^{\circ} \mathrm{C}$ for $24 \mathrm{~h}$. The antibacterial activity was measured as the diameter in millimeter of clear zone of growth inhibition around the well.

\section{RESULTS AND DISCUSSIONS}

Wide range of plant spices are used as active ingredients for the food preparations by the people living in the Asian countries. In the traditional ayurvedic treatments, a number of plant extracts and plant products are used to prepare drugs to treat different human ailments (Bonjar et al., 2004). Different studies have been carried out to understand the role of such plant extracts in human body and their anti-microbial properties (Voravuthikunchai et al., 2005 Vaishnavi et al 2007). Six spices were tested for their antibacterial property against six bacterial pathogens in this present study. All the spices tested have already been confirmed that they have the potential of showing antibacterial activities in general. The results of antibacterial activity of these spices against six pathogens tested are summarized in Table 1 and Table 2. Out of the four types of spices extracts tested, ethanolic and methanolic extracts and nutrient broth extract of spices had demonstrated better activity against pathogenic bacteria than the aqueous extracts of the spices. Alcoholic solvents might have exhibited better solubility of active ingredients of spices than water. Nutrient broth might have provided all the necessary requirements for active growth of bacteria and given highly soluble media for the ingredients. Alcoholic extracts of medicinal plants had greater activity than their aqueous extracts (Ahmad et al., 1998).

Among the spices tested, the extracts of cardamum, clove and lemon grass had shown maximum activity against pathogens than other spices. Cumin, cinnamon grass and nutmeg had shown comparatively less activity. The efficacy of spices was compared between gram negative and gram positive bacteria. Extract of spices like cardamom, cloves, and lemon grass had shown highest antimicrobial zones against gram negative bacteria while cardamum and lemon grass exhibited maximum zones against gram positive bacteria. The gram positive bacteria were more sensitive to the extract of spices than gram negative bacteria because of the differences in the organization and 
components of the cell wall structure (Shihabudeen et al., 2010 and Ceylan and Fung, 2004). Anyway, the present work shows that the spices have been very effective against both gram positive and gram negative bacteria chosen for this study.

The antibacterial activity of the plant extract of spices was compared with the standard antibiotic Penicillin G (10 U/disc) and activity index of spices was determined against gram negative and gram positive bacteria (Figure1 and Figure 2). The activity index values of cardamom, cloves and lemon grass against E.coli were greater than one, while activity index values of cardamom and lemon grass were greater than one against Staphylococcus aureus. This indicates that the spices specified exhibit more antimicrobial activity than the antibiotic penicillin which is the most common used for the infections caused by bacterial pathogens. This study concludes that the extracts of the spices reduce and inhibit the growth of the selected bacterial pathogens. This could also be applied to food borne and food poisoning organisms as diverse spices are used in various food preparations. Thus the present study confirms the therapeutic potential of the generally used spices. This study recommends further investigations on the possibilities of using different spices around the world as supplementary or alternative medicines for bacterial infections.

The antimicrobial potency of these spices may be due to the presence of tannins, saponins, essential oils, phenolic compounds and flavonoids (Aboaba and Efuwape, 2001). Even crude extracts of these spices are active against multidrug resistant strains where modern antibiotic therapy has limited effect. The effect of these spices on these organisms in vivo cannot be predicted from this study. Practical approach using disk plate assays using the size of inhibition zone, to indicate relative antibacterial activity is not adequate to determine the antibacterial nature of these spices (Mishra and Behal, 2010). The clear zone depends on the solubility and rate of diffusion in agar medium and its volatilization. Thus, there is a need for detailed scientific study of traditional spices to ensure their action with diverse bacterial species and this would provide scientific evidence for their efficacies.

Table 1: Antimicrobial activity of spices against gram negative bacteria

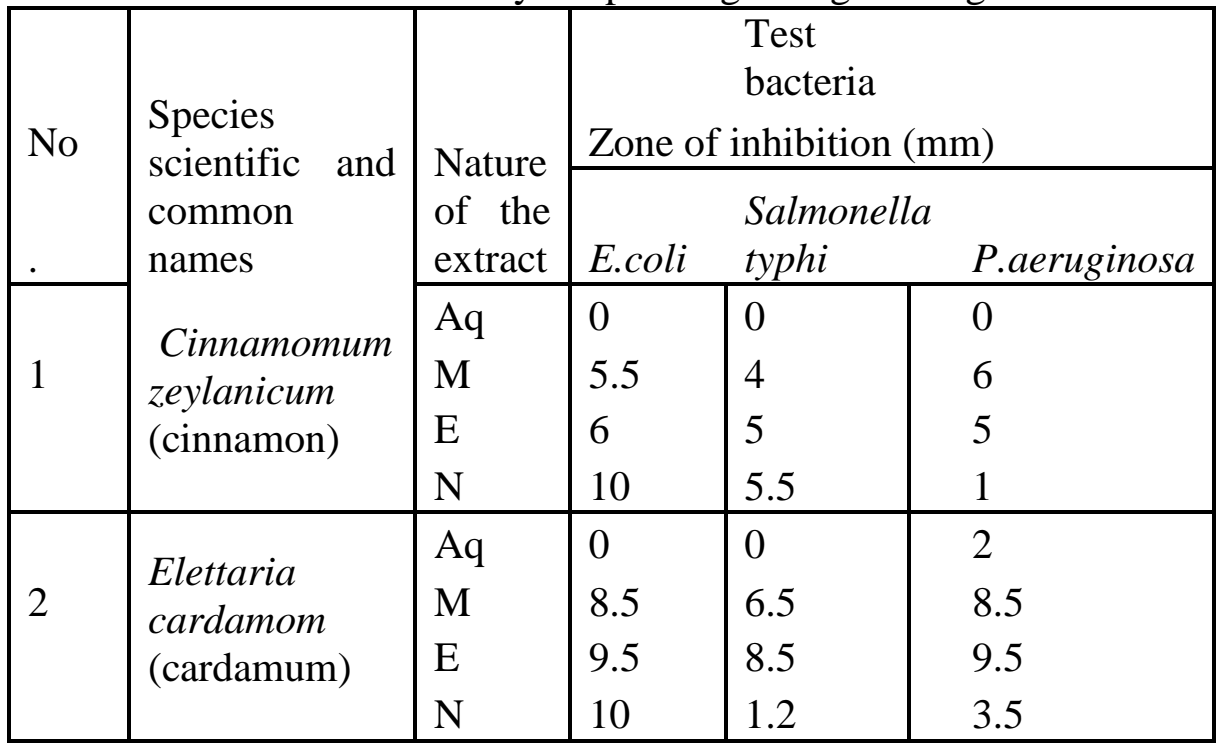




\begin{tabular}{|l|l|l|l|l|l|}
\multirow{5}{*}{3} & Cuminum & $\mathrm{Aq}$ & 0 & 0 & 0 \\
& cyminum & $\mathrm{M}$ & 4.5 & 3.2 & 6 \\
& (cumin) & $\mathrm{E}$ & 5.5 & 3.5 & 9 \\
\hline \multirow{5}{*}{5} & Eugenia & $\mathrm{Aq}$ & 0 & 2.5 & 1 \\
& caryophyllus & $\mathrm{M}$ & 8.5 & 7.5 & 6.5 \\
& (cloves) & $\mathrm{E}$ & 9.5 & 8 & 7.5 \\
& & $\mathrm{~N}$ & 7 & 6 & 3.5 \\
\hline \multirow{5}{*}{6} & Cymbopogon & $\mathrm{Aq}$ & 0 & 0 & 1.5 \\
& citratus & $\mathrm{M}$ & 5 & 5.5 & 7 \\
\hline \multirow{5}{*}{6} & (Lemongrass) & $\mathrm{E}$ & 6 & 8.5 & 7.5 \\
& & $\mathrm{~N}$ & 2.5 & 4 & 7 \\
\hline & Myristica & $\mathrm{Aq}$ & 0 & 0 & 1.5 \\
& fragrans & $\mathrm{M}$ & 5 & 5.5 & 7 \\
& (Nutmeg) & $\mathrm{E}$ & 6 & 8.5 & 7.5 \\
& & $\mathrm{~N}$ & 2.5 & 4 & 7 \\
\hline
\end{tabular}

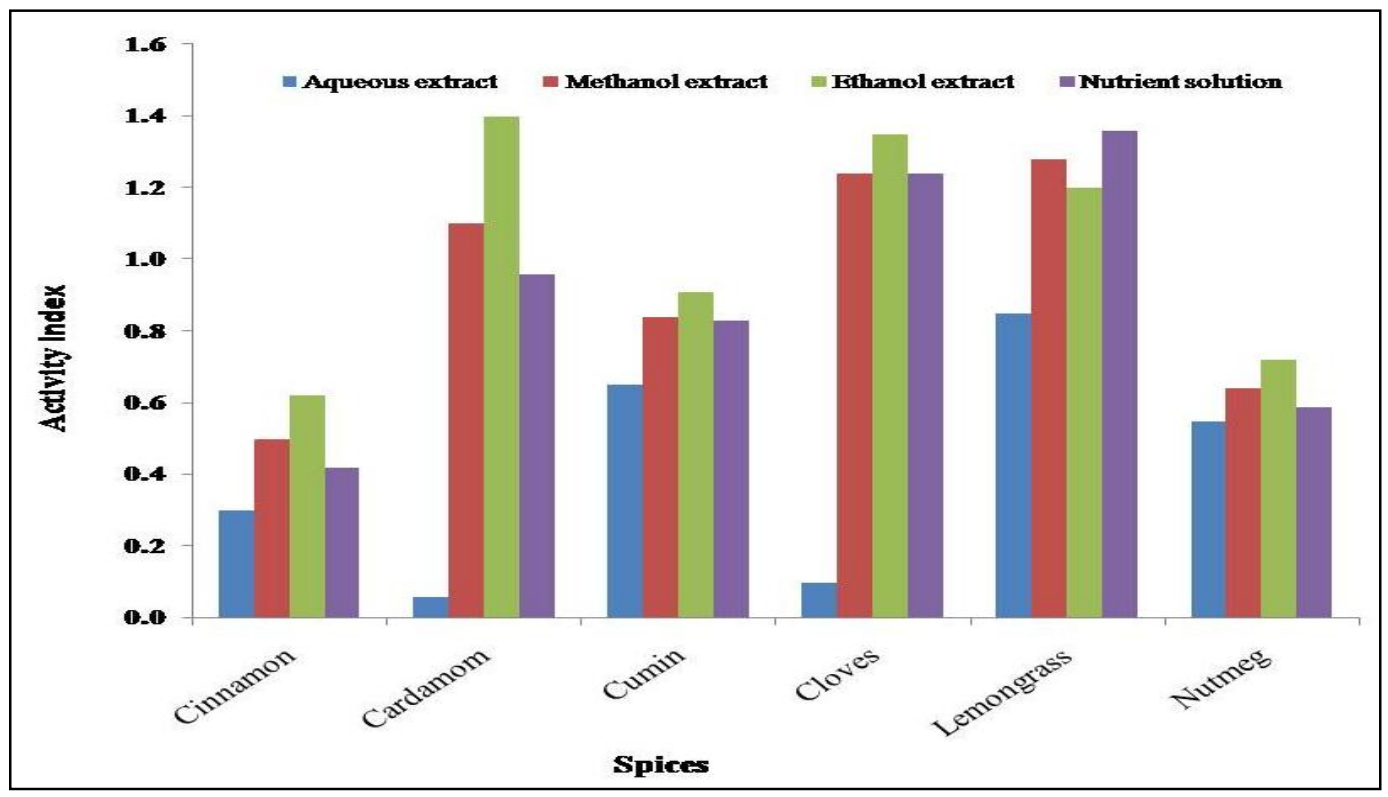

Figure 1: Mean activity Index of spices against gram negative bacteria E.coli 


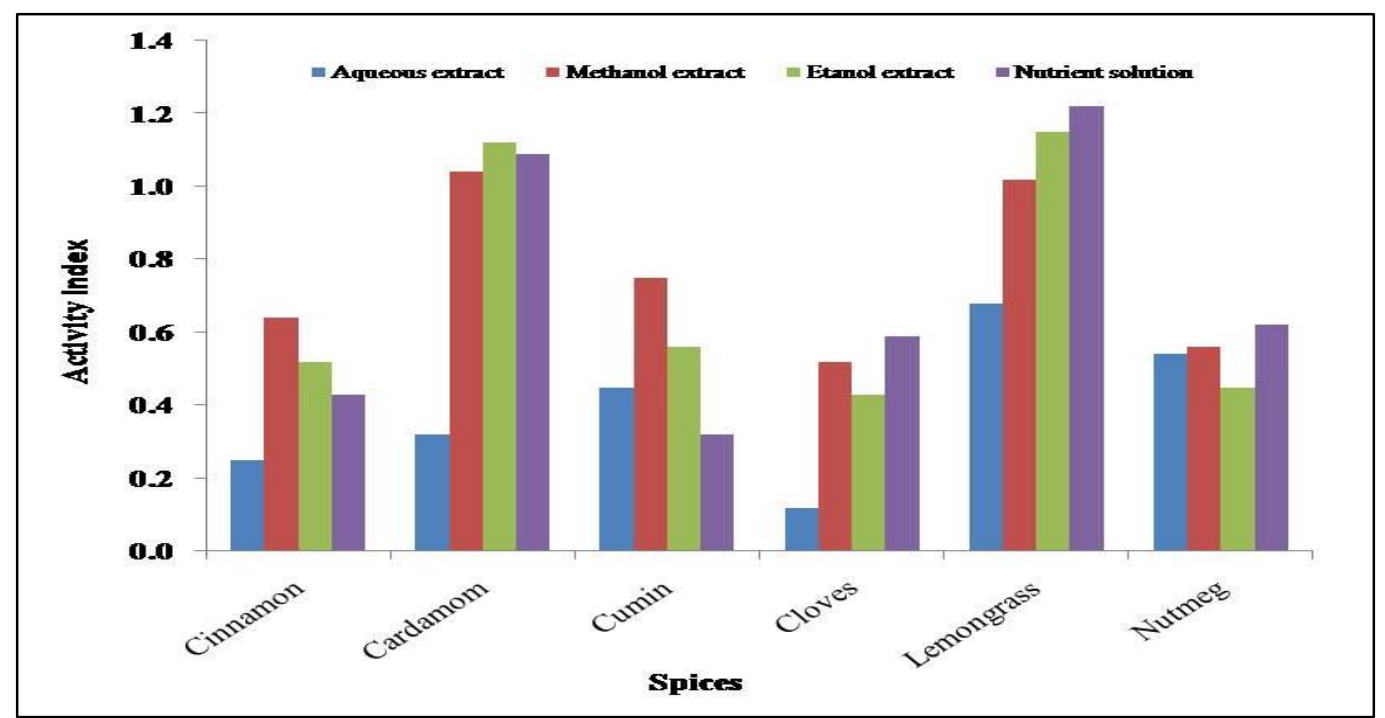

Figure 2: Mean activity Index of spices against gram negative bacteria Staphylococcus aureus

Table 2: Antimicrobial activity of spices against gram positive bacteria

\begin{tabular}{|c|c|c|c|c|c|}
\hline \multirow[t]{2}{*}{ No } & \multirow{3}{*}{$\begin{array}{l}\text { Species } \\
\text { scientific and } \\
\text { common names } \\
\text { Cinnamomum } \\
\text { zeylanicum } \\
\text { (cinnamon) }\end{array}$} & \multirow{2}{*}{$\begin{array}{l}\text { Nature } \\
\text { of the } \\
\text { extract }\end{array}$} & Zone of in & $\begin{array}{l}\text { Test } \\
\text { bacteria } \\
\text { ibition }(\mathrm{m}\end{array}$ & \\
\hline & & & B.pumilus & B.cereus & S.aureus \\
\hline 1 & & $\begin{array}{l}\mathrm{Aq} \\
\mathrm{M} \\
\mathrm{E} \\
\mathrm{N}\end{array}$ & $\begin{array}{l}4 \\
5.5 \\
5.5 \\
6\end{array}$ & $\begin{array}{l}-- \\
6 \\
7 \\
5\end{array}$ & $\begin{array}{l}0 \\
7 \\
5 \\
9\end{array}$ \\
\hline 2 & $\begin{array}{l}\text { Elettaria } \\
\text { cardamom } \\
\text { (cardamum) }\end{array}$ & $\begin{array}{l}\mathrm{Aq} \\
\mathrm{M} \\
\mathrm{E} \\
\mathrm{N}\end{array}$ & $\begin{array}{l}2 \\
7.5 \\
8.5 \\
9\end{array}$ & $\begin{array}{l}3 \\
7.5 \\
9 \\
10\end{array}$ & $\begin{array}{l}3 \\
6 \\
7 \\
6\end{array}$ \\
\hline 3 & $\begin{array}{l}\text { Cuminum } \\
\text { cyminum } \\
\text { (cumin) }\end{array}$ & $\begin{array}{l}\mathrm{Aq} \\
\mathrm{M} \\
\mathrm{E} \\
\mathrm{N}\end{array}$ & $\begin{array}{l}0 \\
4 \\
5 \\
8\end{array}$ & $\begin{array}{l}0 \\
5.5 \\
6 \\
5\end{array}$ & $\begin{array}{l}1 \\
7 \\
6.5 \\
6\end{array}$ \\
\hline 4 & $\begin{array}{l}\text { Eugenia } \\
\text { caryophyllus } \\
\text { (cloves) }\end{array}$ & $\begin{array}{l}\mathrm{Aq} \\
\mathrm{M} \\
\mathrm{E} \\
\mathrm{N}\end{array}$ & $\begin{array}{l}2 \\
8 \\
7.5 \\
7\end{array}$ & $\begin{array}{l}3 \\
6.5 \\
7.5 \\
7\end{array}$ & $\begin{array}{l}1 \\
8 \\
9 \\
3.3\end{array}$ \\
\hline 5 & $\begin{array}{l}\text { Cymbopogon } \\
\text { citratus } \\
\text { (Lemongrass) }\end{array}$ & $\begin{array}{l}\mathrm{Aq} \\
\mathrm{M} \\
\mathrm{E} \\
\mathrm{N}\end{array}$ & $\begin{array}{l}1.5 \\
7 \\
7.5 \\
6\end{array}$ & $\begin{array}{l}3 \\
6 \\
5.5 \\
4.5\end{array}$ & $\begin{array}{l}3 \\
6.5 \\
7.5 \\
8\end{array}$ \\
\hline
\end{tabular}




\begin{tabular}{|l|l|l|l|l|l|}
\cline { 2 - 5 } 6 & Myristica & $\mathrm{Aq}$ & 3 & 2 & 2 \\
& fragrans & $\mathrm{M}$ & 5.5 & 5.5 & 5.5 \\
& (Nutmeg) & $\mathrm{E}$ & 6.5 & 6 & 7 \\
& & $\mathrm{~N}$ & 5.5 & 6.5 & 8 \\
\hline
\end{tabular}

\section{CONCLUSION}

Among all the liquid extracts tested, the alcoholic extracts of cardamom, clove and lemongrass exhibited maximum antibacterial activity against gram negative bacteria while alcoholic extract of cardamom and lemongrass showed maximum antibacterial activity against gram positive bacteria. All the spices tested shows the antibacterial nature but the degree varies among species. The maximum activity index (1.39) was exhibited by the ethanol extract of cardamom against E.coli.

\section{ACKNOWLEDGEMENT}

Author is thankful for the financial support and laboratory facilities provided by Dr.Mohan.Thiagarajah, University of Alberta, Canada, to carry out this research.

\section{REFERENCES}

[1] Abdel Hammiad AA, Nassar AG, El-Badry N (2009). Investigation on antioxidant and antimicrobial activities of some natural extracts. World J Dairy Food Science, 4:01-07.

[2] Aboaba O, Efuwape BM (2001). Antibacterial Properties of Some Nigerian Species.Bio Res Comm, 13:183-188.

[3] Ahmad I, Mehmood Z and Mohammad F, (1998). Screening of some Indian medicinal plants for their antimicrobial properties, J. Ethnopharmacol, 62,183- 193.

[4] Anjeza C, Mandal S. (2012) Synergistic or additive antimicrobial activities of Indian spice and herbal extracts against pathogenic, probiotic and food-sp. International Food Res Journal, 19(3):1185-1191

[5] Arora, D. S. and Kaur, J. (1999). Antimicrobial activity of spices. International Journal of Antimicrobiological Agents, 12: 257- 262.

[6] Avato, P; Bucci R.;Tava R, Vitali C.; Rosato A.; Bilay Z. and Jurzysta M. (2006). Antimicrobial activity of saponins from Medicago sp.: structure-activity relationship Phytotherapy, 40(6):454 -457.

[7] Bonjar, G.H.S. (2004). Screening for antibacterial properties of some Iranian plants against two strains of E. coli. Asian Journal of Plant Sciences, 3(3): 310-314

[8] Bauer A. W., Kirby W.M.M., Sherris J.C. (1966). Antibiotic susceptibility testing by a standardized singledisk method, Am J Clinical Pathology. 45: 493-496.

[9] Ceylon E.and Fung C.Y.D. (2004). Antimicrobial activity of spices, J. Rapid. Meth. Autom. Microbiol. 12:1-55

[10] Chang H.W. (1995). Antibacterial effect of spices and vegetables, Food Ind. (Roc), 27: 5361.

[11] Evans C.E,, Banso A, Samuel O.A. 2002. Efficacy of some nupe medicinal plants against Salmonella typhi: an in vitro study. J.Ethnopharmacol, 80: 21-24 
[12] Gold S.G, and Moellering R.C. (1996). Antimicrobial drug resistance. N. Engl. J. Med. 335: 1445-1453.

[13] Joe M.M., Jayachitra J. and Vijayapriya M. (2009). Antimicrobial activity of some common spices against some human pathogens, J.of Med.Plant Research 3 (11): 1134-1137.

[14] Mishra N. and Behal K.K. (2010). Antimicrobial activity of some spices against some microbes, Inter. J. of Phar. and Pharmaceuti.Sci. 2(3):187-196.

[15] Panpatil,V.V.; Tattari, S.; Kota, N,; Nimgulkar,C.and Polasa K., (2013). In vitro evaluation on antioxidant and antimicrobial activity of spice extracts of ginger, turmeric and garlic .J. Pharmacognosy and phytochemistry,2(3):143-148

[16] Pei S.J. (2001). Ethno botanical approaches of traditional medicine studies: Some experiences from Asia. Pharmaceutical Biology. 39: 74-79.

[17] Perez C, Paul M and Bazerque P. (1990). Antibiotic assay by agar well diffusion method. Acta. Bio Med Exp. 15:113-117.

[18] Shan B, Cai Y.Z, Brooks J.D., Corke H. (2007). The in vitro antibacterial activity of dietary spice and medicinal herb extracts. International Journal of Food Microbiology. 117:112119.

[19] Shihabudeen M.S., Priscilla H.D. and Kavitha T., (2010). Antimicrobial activity and phytochemical analysis of selected Indian folk medicinal plants, Inter. J. Pharma Sci.and Res., 1(10):430-434.

[20] Tenover F.C., Weige L.M., Appelbaum P.C., (2004). Vancomycin-Resistant Staphylococcus aureus Isolate from a patient in Pennsylvania. Antimicrob. Agents Chemother, 48(1): 275-280.

[21] Vaishnavi C, Kaur S. and Kaur M., 2007, Bactericidal activity of kitchen spices and condiments on enteropathogens; Natural Product Radiance. 6(1) 40-45.

[22] Voravuthikunchai, S. P., Phongpaichit, S. and Subhadhirasakul, S. (2005). evaluation of antibacterial activities of medicinal plants widely used among AIDS patients in Thailand. Pharmaceutical Biology 43(8): 701-706. 